\title{
An Account of 'Life after Guantánamo': a rehabilitation project for former Guantánamo detainees across continents
}

\author{
Polly Rossdale, MA Cantab, E.MA, Katie Taylor, MA
}

\section{Key points of interest:}

- Reprieve's Life after Guantánamo (LAG) project suggests the value of a Multidisciplinary Approach in rehabilitation of torture survivors.

- Undertaking advocacy at the same time as rehabilitation made the project more effective and legitimate amongst both users and other political actors.

- LAG guidelines address pre-planning for resettlement, setting up a resettlement team, dealing with the media and mitigating stigma, immediate issues upon an individual's arrival in the new host country and longer term integration planning.

- A security resettlement framework, rather than a humanitarian one, impedes rehabilitation.

- Former Guantánamo detainees found peer support important for their recovery.

\section{Abstract}

This paper describes a project established in 2009 by the human rights charity, Reprieve, to coordinate rehabilitation for men who have been released from long-term detention at the US military base of Guantánamo Bay. The majority of the men referred to the project were deemed unable to return to their home country because of the risk they faced of torture or other persecution and were therefore resettled in a third country.
This paper also refers to Tunisian former Guantánamo detainees with whom Reprieve worked, who had initially been resettled in a third country but then following the Jasmine Revolution and the fall of the Ben Ali regime, were able to return to their home country. Reprieve then provided assistance to them and their families under the Life after Guantánamo in Tunisia project. This paper briefly outlines the abuse and nature of psychological control at Guantánamo and, based on the first-hand experiences of the Project Coordinator and Caseworker, offers non-clinical observations of the apparent consequences of this control on the former detainees who were referred to the project.

The Life after Guantánamo project facilitated social, medical, psychological, legal and financial assistance in partnership with local service providers and through liaison with host governments and intergovernmental organisations, such as the International Organisation for Migration (IOM), United Nations High Commissioner for Refugees (UNHCR) and the International Committee of the Red Cross (ICRC). The paper recounts the type of assistance provided, highlights some of the challenges faced and, based on learnings made over the project's eight year duration, makes recom-

Thanks are extended to Michelle Farrell, BA, LLM, PhD, our guest legal editor, who together with the Editor in Chief jointly edited the in the name of the war on terror section. 
mendations, for future work with former Guantánamo detainees and others who have been detained and subject to torture and inhuman and degrading treatment in the 'War on Terror'.

Keywords: Guantánamo, torture rehabilitation, War on Terror, psychological torture, indefinite detention, torturing environment

\section{Background}

Since 2002, some 780 men have been held at the US military prison at Guantánamo Bay (as at June 17th 2017) (The New York Times, 2017). According to the 2014 report of the Senate Intelligence Committee Study on CIA detention and interrogation program, men held at Guantánamo Bay have been subjected to rendition, torture or other cruel, inhuman and degrading treatment or punishment and indefinite detention, the majority without charge or trial. A 2006 study by Seton Hall Law School of 517 of the detainees indicated that $86 \%$ of the men were 'bounty' prisoners, captured by Pakistani authorities or the Northern Alliance and handed over to the United States for a significant sum of money. Flyers distributed by the U.S. promised "wealth and power beyond your dreams" for those handed over. Only four have, so far, received final convictions by a military commission (US Court of Military Commission - Guantánamo, n.d., Denbeaux and Denbeaux, 2006). An estimated 741 men have reportedly been transferred to 59 countries. However, this number is an estimate because of prisoners who were hidden in CIA-run black sites and because the destination country is not known in 10 cases (The Miami Herald, 25 October 2016, New York Times, n.d.). Of these, 142 men were transferred to third countries under Obama's administration (2009-2016) because of instability in their home country or because they were deemed to face a risk of torture or persecution.

Table 1: Geographical location of resettlement of detainees

Third Countries which Accepted Former Guantánamo Detainees under the Obama Administration

Albania

Belgium

Bermuda

Bosnia and Herzegovina

Bulgaria

Cape Verde

El Salvador

Estonia

France

Georgia
Number of Former Guantánamo Detainees Resettled 


\begin{tabular}{|c|c|}
\hline Germany & 2 \\
\hline Ghana & 2 \\
\hline Hungary & 1 \\
\hline Ireland & 2 \\
\hline Italy & 1 \\
\hline Kazakhstan & 5 \\
\hline Latvia & 1 \\
\hline Montenegro & 2 \\
\hline Oman & 30 \\
\hline Palau & 6 \\
\hline Portugal & 2 \\
\hline Qatar & 5 \\
\hline Saudi Arabia & 13 \\
\hline Senegal & 2 \\
\hline Serbia & 2 \\
\hline Slovakia & 8 \\
\hline Spain & 3 \\
\hline Switzerland & 3 \\
\hline UAE & 23 \\
\hline Uruguay & 6 \\
\hline Total & 142 \\
\hline
\end{tabular}

The nature of the Guantánamo regime has been written about fairly widely and will therefore only be briefly outlined here in order to provide a context for what follows.

${ }^{\text {i }}$ LAG is unable to provide information on the men it worked with in each country as this would mean breaching confidentiality due to the small number resettled in each country to there being so few numbers.
What is considerably less well-known and understood is its effects and the efforts that have been made to assist released men in their recovery.

\section{Conditions and Abuse}

Guantánamo is a regime of isolation and near total control. Despite the fact that the prison is arguably under the greatest public spotlight 
in the world, information about the regime and conditions has been achieved through dogged and pioneering litigation and human rights activism. For example, it was only after the landmark case of Rasul v Bush in 2004 that defence lawyers, including Reprieve's founder Clive Stafford Smith, gained access to the prison (Rasul v. Bush 542 U.S. 466 (2004)). Detainees at Guantánamo initially had no contact whatsoever with the outside world. On arrival in Guantánamo, they had no idea where they were. According to Reprieve clients, they often guessed based on the weather - some thought Brazil, others Qatar. Each step towards greater transparency was hard won as a set of legal and administrative practices was specifically designed to keep things hidden (BBC, 2014). Reprieve lawyers and the staff of the Life after Guantánamo project observed that these practices designed to ensure opacity had significant psychological consequences for the detainees.

\section{Psychological Control}

As highlighted in the US Senate Select Committee on Intelligence's report on CIA torture, published in redacted form in December 2014, interrogation techniques developed for the U.S.' 'War on Terror' detention relied heavily on systematised psychological torture (Senate Intelligence Committee Study on CIA Detention and Interrogation Program, Findings and Conclusions no. 13, 2014).

Interrogation at Guantánamo is based on a military Cold War era programme aimed at training forces in survival and resistance following capture by an enemy: SERE (survival, evade, resist, escape). With the explicit objective of breaking the personality, SERE was reverse engineered so as to extract information rather than support withholding information (Ibid). The psychologists contracted had no experience in interrogation nor relevant cultural or linguistic knowledge. They developed interrogation techniques based on the theory of 'learned helplessness'. According to the Senate Committee Report, in this context this theory referred to the belief that a detainee would become passive and depressed and thereby cooperative in interrogation if subjected to uncontrollable or adverse events (Senate Select Committee on Intelligence: Committee Study of the Central Intelligence Agency's Detention and Interrogation Program, 2014). Practices sought to destroy the sense of self and the relationship to others; in the words of former CIA Director Michael Hayden, for the detainee to "get over his own personality and put himself in a spirit of cooperation." (Senate Select Committee on Intelligence: Committee Study of the Central Intelligence Agency's Detention and Interrogation Program, 2014 p.486).

Health professionals - the very people from whom the men have to seek help - were complicit in or perpetuated this psychological control (The PLoS Medicine Editors, 2011; Borchelt and Fine, Physicians for Human Rights, 2005). Independent reports and Reprieve clients describe how the provision of healthcare was conditional on "cooperation." (Bloche \& Marks, 2005). Psychologists have participated in interrogations. Detainees have been subjected to non-consensual treatment, including the prescription of drugs without being informed of the medication prescribed (Denbeaux, Camoni, Beroth, Chrisner, Loyer, Stout, \& Taylor, 2011).

Guantánamo operates a particular system of indefinite detention. Very few of the men detained there have ever been charged with any crime or tried. It took two and a half years from the first 'War on Terror' use of the prison for the Supreme Court to clarify that U.S. courts had jurisdiction to consider challenges brought by Guantánamo detain- 
ees regarding the legality of their detention (Rasul et al. v Bush, President of the United States, 2004 No. 03-334). However, even if they were cleared for release in the administrative process created to review their detention, they still could, and many did, remain detained.

Being cleared for release, when they had not been charged with a crime, is the closest most of the detainees have got to being 'declared' in some fashion innocent. Detainees and former detainees have made it clear that this 'indefinite detention without trial' generates terrible uncertainty, deep mistrust and hopelessness. ${ }^{\text {ii }}$

More generally the prison system is run on the basis of punishments and incentives (United Nations Economic and Social Council, 2006). Basic necessities, soap and toilet paper, even water, are 'comfort items', given or removed when someone is deemed compliant or not. Men who inform on others are rewarded with anything from hamburgers to pornography (The Guardian, 2013). Punishments include long periods of solitary confinement and force-feeding for hungerstrikers (American Civil Liberties Union Appeal for Justice et al., 2013). Exposure to strobe lights, noise torture, sensory deprivation and sleep disturbance have also been used (Lewis, 2004), as well prolonged isolation, sexual and cultural humiliation (Borchelt \& Fine, Physicians for Human Rights, 2005). Enhanced interrogation techniques included these and other practices such as stress positions, temperature manipulation, beatings, waterboarding and threats of harm (Physicians for Human Rights, 2007, 2008).

\footnotetext{
ii Reprieve client files..

iii www.reprieve.org.uk
}

\section{Life after Guantánamo}

Reprieve is an international Human Rights NGO founded in 1999 by Clive Stafford Smith who was one of the first lawyers to gain access to prisoners at the military base, with a view to defending their rights. ${ }^{\text {iii }}$

Reprieve's lawyers have represented upwards of 80 men detained in Guantánamo. Based on these crucial lawyer-client relationships and, in response to President Obama's Executive Order days after taking office (Executive Order 13492, 22 January 2009), that he would close the prison, Reprieve established 'Life after Guantánamo' (LAG) in 2009 to facilitate access to medical, psychological, social and legal support for former detainees who had been released to third countries. In addition, from 2012, LAG also ran a project in Tunisia, providing direct services to former detainees and their families for the first time.

The tasks of the LAG project are multifarious but consist primarily of advocacy, coordination and pastoral care. Men were either referred to the project by their lawyers or, as LAG's reputation grew, by other former detainees or as self-referrals. Wherever political contexts permitted, staff visited former detainees on or soon after arrival in their new host country to work directly with them, with host governments and international and local NGOs and, where necessary, to identify specialist service providers. Such visits were subsequently supplemented by regular skype and phone contact with the former detainee, their family members, government officials and others responsible for their care.

From 2009 until 2013, the first author was Project Coordinator of Reprieve's Life after Guantánamo project. She then continued her oversight of the project as Deputy Director of the Abuses in Counter Terrorism team. She has a background 
working with refugees and victims of torture and she left Reprieve in 2015. The second author joined Reprieve as Life after Guantánamo Caseworker in 2010. Prior to joining Reprieve she worked in the Middle East, specialising in children's rights. She is now a Deputy Director and has coordinated the Life after Guantánamo project since 2014. The two authors had daily contact with former Guantánamo detainees, conducted dozens of country visits, identified potential partner organisations, developed support plans and advocated on the men's behalf to governments and other stakeholders.

\section{Responding to Needs}

The Life after Guantánamo project followed two different approaches: in Tunisia, LAG established a local multidisciplinary team to provide direct services to former detainees, their families and the families of men still detained in Guantánamo, whereas, in other countries, LAG sought to coordinate and facilitate access to care and services, rather than offer direct provision of the needed social, medical, psychological and legal services.

In 2012 LAG piloted the unique project in Tunisia, setting up the first multidisciplinary torture rehabilitation services after the revolution, and establishing a local team to provide direct psychological, medical, social and legal support. Tunisia was selected for this pilot project for several reasons: the presence of a strong human rights community who had previously worked in semi clandestine conditions under the Ben Ali regime and were now keen to bring human rights actions and discourse into government. Reprieve had had several Tunisian clients in Guantánamo and had established relationships with Tunisian human rights defenders, as well as their clients' families. Reprieve encountered an interest and desire for such a project from all these actors. From
201233 people received assistance through the Life after Guantánamo Tunisia project.

Both inside and outside of Tunisia, former detainees were referred to the project by their U.S. habeas counsel. As the project evolved, former detainees began to refer other former detainees and we also began to receive self-referrals. Once referred to the project, the LAG team would work with the former detainees to assess their rehabilitation goals and the obstacles that the project could meaningfully address in order to reach their goals. Family reunification was often key to former detainees' stated goals, and so LAG treated the family unit as integral to rehabilitation. Therefore, particularly in the Tunisian project, key family members themselves became beneficiaries of the project and engaged with the LAG team on goal-setting to address their status as victims of secondary-trauma.

Once a beneficiary's goals were established through conversations with the LAG team, and the obstacles to those goals identified, the LAG team would work to identify needed services to address these obstacles whether they were social, legal or medical. This is where the work in Tunisia differed; whereas elsewhere, Reprieve would identify, sensitise and coordinate local services, in Tunisia several factors made the provision of direct services viable and valuable. There was a dearth of available existing specialist rehabilitation services in Tunisia but professionals were keen to offer support to this group of men, recognising that they were victims of injustice and torture. Moreover, these professionals were able to provide culturally appropriate assistance in the men's native language. This meant that the best solution there was to recruit and train a multidisciplinary team including a doctor, psychiatrist and social workers who could directly provide medical, 
psychological and social care.

The level of contact depended upon the wishes of the beneficiary and his/her specific circumstances. Regular follow up meant that LAG could facilitate new services in response to a beneficiary's evolving rehabilitation needs. There was no formal exit of the project; rather, beneficiaries would reach a stage where they felt that LAG's support was no longer needed.

In relation to LAG's work beyond Tunisia, in third countries, the support and assistance for former detainees involved a complex web of actors, which complicates the possible assessment of impact. The discussion below is based on a review of LAG's case files of 73 former detainees and family members from August 2009 - June 2015 in 21 countries and describes only the type of assistance LAG offered. The types of assistance offered were based on the goals established by the beneficiaries in discussion with the LAG team and what was practical and within the remit of the project.

Across all of LAG's work, the majority of interventions were social: LAG provided social assistance in 62 cases (85\%). Social care included liaison with host governments, NGOs and private landlords to deal with housing issues, to facilitate access to financial support, language learning, vocational training, other job-seeking support and general integration and country orientation. This work included advocating with the host countries' governments to provide a consistent and suitable stipend for resettled men and sourcing external funding for needed educational programmes and vocational training.

In $50 \%$ of cases (37) LAG offered healthcare-related assistance - facilitating physical or psychological care. Health-related interventions included sourcing funding and arranging for medico-legal evaluations and for emergency surgery; obtaining independ- ent second opinions on medical examination results; the provision of direct medical and psychiatric care to beneficiaries in Tunisia through the three-year project there.

LAG conducted legal interventions in 27 cases $(37 \%)$. For many of the men resettled in third countries, their legal status was either unclear or the rights that accrued to that status were undefined or there was no obvious legal pathway to regularisation of their status. The majority of legal interventions therefore involved identifying or working with a local lawyer to regularise immigration status. In a handful of cases LAG took witness statements and instructed other counsel in relation to tort claims over governments' complicity in the U.S.' detention programme and the resulting rendition and torture. Twelve clients were re-imprisoned after release from Guantánamo, either in immigration detention as a result of being resettled without a clear legal status, or as a result of governments re-detaining men on the basis of discredited allegations which followed them from Guantánamo. LAG assisted in efforts to secure the release of seven of these men, working with local counsel and conducting media advocacy.

It should be noted that the absence of an intervention does not indicate an absence of need. In some cases, LAG staff were aware of needs which could not be met by the project because staff were not permitted to visit the country or because those needs fell outside the remit of the project.

\section{Challenges: Impact of detention,} organisational and political

Observations on the impact of Guantánamo detention: At the beginning of the project in 2009, one former Guantánamo detainee asked: "What do you even do? What is this Life after Guantánamo Project? If you call it 
that, you have to give life." This man was expressing the sense that the Guantánamo regime destroys the feeling of being alive. Any rehabilitation project needs to be aware of and address the depth and longevity of this experience. Furthermore, the men's expressed feeling of the utter destruction of their lives in the wake of Guantánamo detention demonstrates the urgent need for a dedicated and holistic rehabilitation programme tailored to their unique experiences and circumstances.

Guantánamo detainees have been exposed to prolonged periods of traumatic events from their initial capture and extraordinary rendition onwards. Over the course of the eight years of the LAG project's existence so far, the authors have observed certain patterns of behaviour on release and resettlement which would fit within a range of Post Traumatic Stress Disorder symptoms such as persistent insomnia, memory loss, inability to concentrate, disturbances in executive functions. These and other symptoms that include confusion, anger and the inability to trust are well known sequelae of torture (Turner and Gorst, 1993). In Guantánamo mistrust and paranoia have also arisen as a result of specific circumstances: sensory deprivation, isolation, inhumane treatment, humiliation and attacks to identity, the indefinite nature of the detention, administrative and legal practices that exert psychological control, a profound sense of personal injustice, opacity and deception. A lack of confidence is especially noteworthy. According to Reprieve clients, interrogators often pretended to be a doctor or the Red Cross (ICRC) or a detainee's defence lawyer. All lawyers have to be U.S. citizens in order to obtain the security clearance required to work in Guantánamo but Reprieve clients reported that when they first met an American who introduced themselves as their lawyer, it was hard to trust that they were indeed who they said they were. Some also reported being put on a plane and told they are going home, only to be returned to their cell or moved to another part of the camp. Paranoia and mistrust after many years of experiencing such practices are logical responses to illogical events.

The authors observed a tendency on release for former detainees participating in the project to see the world outside of Guantánamo as structured like Guantánamo and to behave and act accordingly. To many of these men, the outside world may not feel metaphorically like Guantánamo but as though it really is Guantánamo. A former detainee may not feel the difference between walking freely down an elegant Central European street and sitting in a steel cell in Camp V. "I am in a big Guantánamo," said one. ${ }^{\text {iv }}$ Acts of refusal become the main coping mechanism - often making use of the body, the only thing over which the men had some control during their incarceration.

Hence, hunger strikes to protest indefinite detention without charge, when outside become hunger strikes to protest an amorphous, ill-defined sense of injustice, articulated as a fitting protest for a meagre stipend or a perceived failure on the part of a caregiver (Reuters, 2010; The Miami Herald, 1 September 2016).

Former detainees who for years have largely only been able to articulate their needs through demands made to military guards, for toilet paper or improved food for example, came to expect that relationships in the outside world would operate on a similar demand-response basis. For example LAG project staff observed that some former detainees would focus on seeking to improve

\footnotetext{
${ }^{\text {iv }}$ Reprieve client file.
} 
the minutiae of daily living conditions rather than securing a suitably protective legal status. Similarly, the authors observed that one aspect of this institutionalisation was how the punishment and incentive regime continued to play out, outside of Guantánamo. Thus for instance, men may perceive an electrical power cut or poor internet reception as a personal affront - a targeted unjust punishment which must be remedied immediately_rather than an everyday annoyance experienced by many. Injustice and broken promises in Guantánamo become a perceived schema of unfairness and broken promises in the outside world.

One former detainee described the impact of this particular form of institutionalisation very poignantly: "I thought actually before I was released 'I can cope with this, no problem, I've survived Guantánamo, I can survive normal life.' Actually I found normal life at that stage was harder than Guantánamo. I could deal with, I learned how to deal with GTMO. I can deal with the officers, I can deal with the guards, I can deal with the six or seven people who come into my cell and have a fight with me, but actually I could not deal with [normal] people."v

The result is that for some the "normal world' feels impossible and their response is: "I'm going back to Gtmo where I just eat and sleep and wait for the end of my life". "My future is black. I won't live longer than 10 years". ${ }^{\text {ii }}$ There is the challenge of re-learning to distinguish the different roles of those with whom they interact. Guantánamo's world was small, myopic even: interactions were limited to the guards and (depending on the security level) to other prisoners, occasionally to a military doctor or a psychologist, rarely to a lawyer or a delegate of the ICRC. On release there may be a tendency to see and treat everyone as part of a small, intimate world. In the absence of any apology, acknowledgement or legal redress, an overwhelming sense of non-specific injustice permeates everything. When the service provider is not distinguished from the original perpetrator there is a barrier to assistance. ${ }^{\text {vii }}$ Thus, one of LAG's vital functions is to sensitise service providers to these particular perceptions and work with both them and the former detainees to build a relationship of trust so that the assistance provided was both appropriate to the former detainees' needs and offered in a way that the men are able to benefit from it.

The enormity of the injustice is also sometimes mirrored by a concomitant personal grandiosity. Grandiosity in a psychological sense is usually defined in terms of an inflated sense of self-importance, an exaggerated belief in one's power or uniqueness. Whilst the authors have noted in multiple cases examples of apparently grandiose behaviours, they are not aware of any instances where a psychiatric diagnosis has been made that takes account of this type of symptomatology. Rather, over time and experience, LAG staff came to see this behaviour as a natural sequela of previous impotence when in Guantánamo incongruously coupled with their role on the international political stage simply by virtue of being Guantánamo detainees. The result of this for the former detainees and for the LAG project was a further layer of unrealistic expectations of what post-release life should be like. This poses challenges both for the

\footnotetext{
${ }^{\mathrm{v}}$ Reprieve client file.

${ }^{v i}$ Reprieve client files.

vii This could be seen as part of the tendency towards overgeneralization amongst trauma victims and negative assumptions. See 'Schema Change Perspectives on Post Traumatic Growth', R. Janoff Bulman in Handbook of Posttraumatic Growth: Research and Practice, eds. Lawrence Calhoun and Richard Tedeschi. p.86. 2006. New York.
} 
project, in terms of managing expectations, and for the men themselves in both psychological and practical terms.

The U.S. authorities repeated that the men who were detained in Guantánamo are the "worst of the worst", so bad that the old rules don't apply to them and new ones must be found. The men have been singled out and fashioned with a grandiose narrative around them by others: former Secretary of Defence Donald Rumsfeld told us that these men were "among the most dangerous, best trained, vicious killers on the face of the earth." (The New York Times, 2002). Then, after release, the Guantánamo regime, which has been omnipotent in the daily lives of the prisoners, continues symbolically in terms of global power and high-level intervention. In order to be released they are not subject to the ordinary rule of law; a court order on its own will not guarantee release, but the signature of the U.S. Secretary of Defence is required and they are subject to the whims of Congress, to diplomatic negotiations and political deals conducted with foreign governments by a Special Envoy within the State Department. ${ }^{\text {viii }}$ It does not seem surprising if some of this external political narrative is absorbed internally, possibly as a psychological defence, albeit in complex and indirect ways.

A further response to omnipotent control is to 'split'. This defence mechanism involves dividing helpers into good and bad, communicating different messages to each and setting some up to fail. This challenge to service providers and caregivers requires very tight communication and coordination in response.

Lastly, self-referential thoughts, feelings and perceptions can sometimes lead to paranoia amongst former detainees. As with the sense of injustice, what the men experience once out of Guantánamo is grounded in reality as the suspicion and mistrust is based reasonably on past experience. Former detainees have been surveilled, monitored and harassed and even re-imprisoned after release. Some are constantly shadowed. Security services have approached even those that a former detainee may have casually spoken to, advising them to avoid "retired terrorists" and they have reportedly told landlords to evict former detainees. On the other hand, this everyday reality can tip over into paranoia. The huge difficulty for these often surveilled men therefore is in making an accurate judgement of their environment: when is a landlord evicting them because they simply no longer want them as a tenant and when is it because he has been told to do so by the security services? At LAG, we are reminded often of the saying, just because you're paranoid doesn't mean they are not after you.

Organisational challenges: Many former detainees were sent to States that have little tradition of welcoming refugees, and little or no welfare infrastructure. Some have only a very small and isolated Muslim community. The majority of governments - whatever the nature of the regime - have opted to place the resettlement programme in the hands of the security services, rather than officials from the Ministry of Immigration, Social Affairs or Health or NGOs with experience working with refugees or torture survivors. Framing former Guantánamo detainees as potential security threats rather than as torture victims seeking refuge has the effect

\footnotetext{
viii For a brief summary of the efforts to close Guantánamo and the legislative and political obstacles see 'With final detainee transfer, Obama's Guantánamo policy takes its last breath', Missy Ryan and Julie Tate, Washington Post. 28 Dec 2016.
} 
of replicating many of the abuses of their detention including perpetuating arbitrary systems of control and demonization.

There are common and identifiable patterns across resettlements, such as the reliance on a security rather than humanitarian framework described above. However, men imprisoned in Guantánamo have been released to fifty-nine different countries and each resettlement context is different and poses new challenges. Any overarching, international rehabilitation project needs to be agile and open to respond to these new settings appropriately.

Political challenges: In the case of Guantánamo, the notoriety of the name is doubleedged. The media and political attention paid to these cases offers a platform on which to re-examine the narrative of the "War on Terror'. This has value in itself and can foster an atmosphere conducive to rehabilitation where the individual's voice and story is truly heard. On the other hand, the media is ready to exaggerate any perceived failure. For instance, the failure of a former detainee to hold down a job within a year of release has been the subject of criticism in the national press. As outlined above, excessive attention can feed grandiose behaviours and facilitates the kind of transactional demand-and-response relationships that were nurtured so corrosively in the prison.

\section{Findings}

Over the last eight years LAG staff have observed certain consistent findings and developed recommendations that may be usefully applied across various country contexts.

The Value of a Multidisciplinary Approach: Since the effects of torture are multiple, many torture rehabilitation programmes around the world are multidisciplinary
(Jaranson \& Quiroga, 2011). The LAG team shared the view that a multidisciplinary approach was imperative to support former Guantánamo detainees' rehabilitation needs: progress made in one aspect of a beneficiary's life could be rendered meaningless by a crisis in another aspect. For instance, social goals, such as language-learning, were often undermined by an insecure legal status which prevented former detainees from imagining a safe future in their host countries. This sense of insecurity, combined with a difficulty in focusing characteristic of survivors of torture makes tasks such as new language acquisition much more challenging. There is also a practical aspect: former detainees would question the value of learning a new language such as Hungarian, Georgian or Kazakh, if they did not know how long they would be permitted to reside in the country.

In a context where there is no legal remedy or redress, such as Guantánamo, the importance of broadly conceived reparations is even greater for moral, strategic and for therapeutic reasons. In the absence of compensation or formal redress, the provision of rehabilitation support can itself be reframed as an aspect of reparation.

Peer support and the value of 'Brotherhood': It is important to note that this project supported only a small percentage of detainees ever released from Guantánamo and that the vast majority of former Guantánamo detainees deal with life and try to recover without any professional support whatsoever.

Many former Guantánamo detainees relied primarily on each other as their primary source of support, indeed, they are the only people who really know what the experience was like.

Until very recently all recovery from the ordeal of Guantánamo detention took place 
in the context of many of the men's friends, their 'brothers', still being detained. Naturally, after release, many were preoccupied by the fate of those they had left behind. In this regard, the Life after Guantánamo project had an advantage: knowing that the project and legal colleagues at Reprieve are assisting their 'brothers' still in prison was important to trust-building and a sense that notwithstanding the personal battles they were facing, others are enduring worse. Reprieve's dual role of representing men in Guantánamo and offering rehabilitation upon release therefore meant that firstly, prior knowledge of Reprieve and its staff made the men more open to receiving assistance from LAG and secondly, because of the ongoing legal assistance provided to their detained 'brothers', increased the benefit former detainees saw in the rehabilitation.

The value of advocacy in a rehabilitation project: Reprieve's advocacy can complement rehabilitation coordination and adds value by helping to challenge the narrative that all Guantánamo detainees are guilty of crimes of terrorism: a fallacy that perpetuates stigma and inhibits recovery. ${ }^{\mathrm{ix}}$ In 2012 and early 2013 in Tunisia, LAG engaged in advocacy with the new Tunisian government urging it to bring their citizens home. This dialogue also facilitated other discussions between LAG and government officials about the

ix Similarly, it has been suggested that public awareness of trauma impacts the outcomes of PTSD, with greater awareness reducing the stigma. (Purtle, Lynn, \& Malik, 2016)

x Due to the sensitivity around Guantánamo releases LAG often worked bilaterally. These guidelines were shared with individual governments that expressed an interest in learning from past experiences of releases. rehabilitation of those who were already home. Beneficiaries told staff that the programme's dual role in supporting their rehabilitation and advocating for the release of those still detained in Guantánamo was important to them.

\section{Best Practice Guidelines ${ }^{\mathrm{x}}$ : The Life after} Guantánamo project developed Best Practice Guidelines for governments that had agreed to resettle men released from the US military prison at Guantánamo Bay. The guidelines address pre-planning for the resettlement, setting up the resettlement team, dealing with the media and mitigating stigma, immediate issues upon an individual's arrival in the new host country and longer term integration planning. These guidelines were based on principles LAG had sought to put in place that would facilitate recovery by being diametrically opposed to the Guantánamo regime. After years of indefinite detention and arbitrary rules and punishments, the guidelines recommend clarity, flexibility and transparency as key principles in resettlements. This applies to all aspects of the resettlement from the amount of financial support, to the legal status, freedom of movement, family reunification, to the duration of support. Trained by a clinical psychologist and trauma specialist LAG developed collaborative goal-setting as a useful tool because any assistance designed without the men's input is likely to be perceived as an imposition and rejected; long term integration planning should be developed in partnership.

\section{Final remarks and recommendations}

The effectiveness of LAG's approach to rehabilitation has received recognition. Guantánamo's Periodic Review Board, the administrative body established by President Obama, which determined whether detainees 
can be cleared for release, cited support from Reprieve's 'Life after Guantánamo' project as a positive factor supporting a decision to clear a detainee for release.

Reprieve's LAG project seeks local and international partnerships and cooperation and is guided by the articulated goals and needs of the former detainees. In one sense however, LAG staff are not, or at least not always, "on the front line". Former detainees also sometimes receive crucial assistance from doctors, psychologists, psychiatrists and social workers in their new host country. These professionals may work for the government, for NGOs, IGOs or independently in private practice. Several experts from IRCT member centres have provided medical and psychological support. One suggestion to take LAG's findings forward would be to establish a network through which these professionals could provide more systematised support, exchange experiences, evaluate treatments and develop further recommendations and best practice.

In Guantánamo ‘due process’ was sacrificed at the altar of a politics of fear. After years of being built up as "the worst of the worst" during detention, there follows on release the flurry and the unbearable weight of expectations of what freedom might mean. The men are faced with the difficulty of what freedom actually is. Often the tools they have to cope with this are institutionalized ones, incentivised and transactional.

The guiding principles for rehabilitation and reintegration for these men have to be based on undoing the psychological internalization of the regime. Hence the value of clarity, transparency, flexibility and beneficiary goal-setting. Recovery from the trauma of Guantánamo can build on the sole positive aspects of the detention experience: the importance of a sense of 'good' brotherhood and ultimately the strength inherent in the fact of survival.

\section{Acknowledgements}

Acknowledgement should be given to $\mathrm{Dr}$ Brock Chisholm, a co-founder of Trauma Treatment International, who trained the LAG Tunisia team on topics that included mental health difficulties of SERE survivors, assessment tools, treatment planning and goal setting.

The authors would particularly like to thank the members of the Life after Guantánamo Tunisia team, Rim ben Ismail, Dr Zeineb Abroug, Dr Elias Ben Daoud and Sana Rebhi. In particular, we pay tribute to the compassion and dedication of Drs. Abroug and Ben Daoud who have both since passed away. 
References

American Civil Liberties Union Appeal for Justice et al (2013). 'Joint letter to Chuck Hagel on the force-feeding of hunger-striking prisoners at Guantánamo Bay. Retrieved from https://www. hrw.org/news/2013/05/13/joint-letter-chuckhagel-force-feeding-hunger-striking-prisonersguantanamo-bay.

American Psychologist Association. (2015). Diagnostic and Statistical Manual of Mental Disorders (DSM-5) (5th Edition).

BBC (2014). Guantanamo Bay: Force feedings that test US secrecy. 10 Oct 2014. Retrieved from http://www.bbc.co.uk/news/magazine-29556641.

Borchelt, G., Fine, J. (2005) Break them Down: Systematic Use of Psychological Torture by U.S. Forces. Physicians for Human Rights. Retrieved from https://s3.amazonaws.com/PHR_Reports/ break-them-down.pdf.

Bulman R.J. (2006). Schema Change Perspectives on Post Traumatic Growth. In Calhoun, L. and Tedeschi, R. (Eds.), Handbook of Posttraumatic Growth: Research and Practice. New York.

Denbeaux, M., Denbeaux, J. (2006). Law Report on Guantanamo Detainees. A Profile of 517 Detainees through Analysis of Department of Defense Data. Retrieved from http://law.shu. edu/publications/guantanamoReports/guantanamo_report_final_2_08_06.pdf.

Denbeaux, M., Camoni, S., Beroth, B., Chrisner, M., Loyer, C., Stout, K., Taylor, P. (19 May 2011) Drug Abuse. An exploration of the government's use of mefloquine at Guantanamo. Seton Hall Law School. Retrieved from http://law. shu.edu/ProgramsCenters/PublicIntGovServ/ policyresearch/upload/drug-abuse-explorationgovernment-use-mefloquine-gunatanamo.pdf.

Executive Order 13492. (2009). Review and Disposition of Individuals Detained at the Guantánamo Bay Naval Base and Closure of Detention Facilities. Retrieved from https://www.gpo.gov/fdsys/ pkg/FR-2009-01-27/pdf/E9-1893.pdf.

Gregg Bloche, M., and Marks, J.H (2005) Doctors and Interrogators at Guantanamo Bay. N Engl J Med 2005; 353:6-8 July 7, 2005 DOI: 10.1056/NEJMp058145. Retrieved from http://www.nejm.org/doi/full/10.1056/ NEJMp058145\#t=article.

Guardian, The (2013). 'CIA turned Guantánamo Bay inmates into double agents, ex-officials claim. 26 Nov 2013.

Iacopino, V. \& Xenakis, S.N. (2011). Neglect of Medical Evidence of Torture in Guantánamo Bay: A Case Series. PLoS Medicine. https://doi. org/10.1371/journal.pmed.1001027
Jaranson, J., and Quiroga, J. (2011). Evaluating the services of torture rehabilitation programmes: history recommendations. Torture Vol 21(2).

Lewis, N.A., (2004). Red Cross Finds Detainee Abuse in Guantánamo. The New York Times 30 Nov 2004. Retrieved from http://www.nytimes. com/2004/11/30/politics/red-cross-finds-detaineeabuse-in-guantanamo.html on $28 \mathrm{Feb} 2017$.

Mehta, C. and Dougherty, S. (December 2015). Truth Matters: Accountability for CIA Psychological Torture. Physicians for Human Rights. Retrieved from https://s3.amazonaws.com/ PHR_Reports/truth-matters.pdf.

Miami Herald, The (1 September 2016) 'Friend says ex-Guantánamo detainee weak from hunger strike'. Retrieved from http://www.miamiherald. com/news/nation-world/world/americas/guantanamo/article99337517.html.

Miami Herald, The (25 October 2016). By the Numbers, Retrieved from http://www.miamiherald. $\mathrm{com} /$ news/nation-world/world/americas/guantanamo/article2163210.html.

New York Times, The (n.d.) Guantanamo Docket, Retrieved from https://www.nytimes.com/interactive/projects/guantanamo/transfer-countries.

Physicians for Human Rights \& Human Rights First (August 2007) Leave no Marks. Enhanced Interrogation Techniques and the Risk of Criminality. Retrieved at https://s3.amazonaws.com/ PHR_Reports/leave-no-marks.pdf.

Physicians for Human Rights (2008) Broken Laws, Broken Lives. Medical Evidence of Torture by US Personnel and its Impact. Retrieved at https://s3.amazonaws.com/PHR_Reports/BrokenLaws_14.pdf.

Purtle, J., Lynn, K., and Malik, M. (2016) Calculating The Toll Of Trauma" in the headlines: Portrayals of posttraumatic stress disorder in the New York Times (1980-2015). American Journal of Orthopsychiatry, Vol 86(6), 2016, 632-638.

Rasul et al. v. Bush, President of the United States et al. (2004) No. 03-334. http://caselaw.findlaw. com/us-supreme-court/542/466.html.

Rasul v. Bush 542 U.S. 466 (2004). Retrieved from https://supreme.justia.com/cases/federal/ us/542/466/.

Reuters, 'Guantanamo detainees in Slovakia enter hunger strike' (24 June 2010) Retrieved from http://uk.reuters.com/article/idUKLDE65N220.

Ryan, M., and Tate, J. (2016) With final detainee transfer, Obama's Guantanamo policy takes its last breath. The Washington Post 28 Dec 2016. Retrieved from https://www.washingtonpost. $\mathrm{com} /$ world/national-security/with-final-detainee- 
transfer-obamas-guantanamo-policy-takes-itslast-breath/2016/12/28/dfdf8cb2-cd0f-11e6a747-d03044780a02_story.html?utm_term=. b03165e $57 \mathrm{~d} 49$ on 28 Feb 2017.

Seelye, K. (2002) A nation challenged: captives; Detainees Are Not P.O.W.'s, Cheney and Rumsfeld Declare. The New York Times 28 Jan 2002. Retrieved from http://www.nytimes. $\operatorname{com} / 2002 / 01 / 28 /$ world/a-nation-challengedcaptives-detainees-are-not-pow-s-cheney-andrumsfeld-declare.html on $28 \mathrm{Feb} 2017$.

Senate Intelligence Committee Study on CIA Detention and Interrogation Program (2014). Retrieved from https://www.feinstein.senate.gov/ public/index.cfm/senate-intelligence-committeestudy-on-cia-detention-and-interrogationprogram.

Senate Select Committee on Intelligence: Committee Study of the Central Intelligence Agency's Detention and Interrogation Program (2014). Retrieved from https://www.feinstein.senate.gov/ public/_cache/files/7/c/7c85429a-ec38-4bb5968f-289799bf6d0e/D87288C34A6D9FF736F9459ABCF83210.sscistudy1.pdf

Turner, S., and Gorst, C., (1993) The Psychological Sequelae of Torture. In: International Handbook of Traumatic Stress Syndromes. Wilson, J.P. and Raphael, B. (Eds.). New York: Plenum Press. Retrieved from https://www.freedomfromtorture.org/sites/default/files/documents/ Turner\%26Gorst-Unsworth-PsychologicalSequelaeOfTorture\%20.pdf.

United Nations Economic and Social Council (2006). Situation of detainees at Guantanamo Bay: Joint Report of Special Procedures of the UN Commission on Human Rights, 15 Feb 2006. Retrieved from http://dag.un.org/bitstream/ handle/11176/259174/E_CN.4_2006_120-EN. pdf?sequence $=3$ \&isAllowed $=y$

US Court of Military Commission - Guantanamo (n.d.). Retrieved from http://www.mc.mil. 